American Journal of Animal and Veterinary Sciences 7 (2): 80-83, 2012

ISSN 1557-4555

(C) 2012 Science Publications

\title{
The Splay Leg Syndrome in Piglets: A Review
}

\author{
Vassilis G. Papatsiros \\ Faculty of Veterinary Medicine, Clinic of Medicine \\ University of Thessaly, 43100, Karditsa, Greece
}

\begin{abstract}
Problem statement: The splay leg syndrome is the major congenital cause of lameness in suckling piglets. It is characterized by a temporarily impaired functionality of the hind leg muscles immediately after birth, resulting in an ability to stand and walk. Etiology and pathogenesis is complex and remain still poorly understood. Approach: The aim of the present study is to perform the update information about the etiology, clinical signs and control strategies of the syndrome. Results: A sexaffected inheritance of the splay leg syndrome is assumed since higher frequencies have been observed in male piglets. Several biochemical and histomorphological investigations indicate an immaturity of the skeletal muscle in the affected piglets at birth. Splay leg is caused by a reduction of the axonal diameter and myelin sheath thickness of the fiber that innervate the hindlimb adductors. The existence of one or more major genes for congenital splay leg seems possible. Among the fragments strongly displayed in the splay leg muscle, are identified the porcine CDKN3 gene. Various management and genetic factors have been connected with the etiology, such as the farrowing induction, low birth weight, short gestation lengths, slippery floors and breeds (e.g., Large White and Landrace). Moreover, nutrition can play a role to pathogenesis, as choline or methionine deficiency in sow diets and the fusarium toxicity. Furthermore, Porcine Reproductive and Respiratory Syndrome Virus (PRRSV) are also involved in etiological factors. Piglets suffering from splay leg should be kept in a warm place and be helped to take colostrums or artificial milk for 2-3 days. Conclusion: Management practices should be applied in order to be avoided the occurrence of splay leg syndrome, such as non-slip floors, use of anti-mycotoxins products in feed, avoiding the farrowing induction before day 113. Finally, a herd health management programme should be applied in order to prevent and control PRRSV infection.
\end{abstract}

Key words: Porcine Reproductive and Respiratory Syndrome Virus (PRRSV), skeletal muscle, piglet, splay leg

\section{INTRODUCTION}

The splay leg syndrome was first recognized as a hereditary disorder by Thurley et al. (1967). It is the major congenital cause of lameness in suckling piglets and it is the most frequent observation amongst hereditary disorders in swine (Partlow et al., 1993). The congenital splay leg syndrome is characterized by a temporarily impaired functionality of the hind leg muscles immediately after birth, resulting in an ability to stand and walk (Thurley et al. 1967). It affects approximately $0.4 \%$ of live births (Ward, 1978) and is a widespread problem for the swine industry, affecting typically only 1-4 pigs per litter and just a few litters at a time. Usually individual herd prevalence is less than $1 \%$; however, sporadic increases occur when the prevalence reaches $8 \%$ or higher (Ward and Bradley, 1980). Losses among affected piglets can amount to $50 \%$, making congenital splay leg to a source of considerable economic losses in pig production
(Dobson, 1968). The purpose of the present study is to perform the update information about the etiology, clinical signs and control strategies of the syndrome.

Etiology/pathogenesis: Etiology and pathogenesis of splay leg syndrome is complex and remain still poorly understood. However, a sex-affected inheritance of the splay leg syndrome is assumed since higher frequencies have been observed in male piglets than in female piglets (Lax, 1971; Sellier and Ollivier, 1982).

Several biochemical and histomorphological investigations indicate an immaturity of the skeletal muscle in the affected piglets at birth (Bergmann, 1976; Hillert et al., 1987; Prange et al., 2001). Some researchers reported muscle hypoplasia as the cause of the clinical signs, but myofibrillar hypoplasia is normal in all newborn pigs. Splay leg is caused by a reduction of the axonal diameter and myelin sheath thickness of the fiber that innervate the hindlimb adductors (Szalay et al., 2001). 
The existence of one or more major genes for congenital splay leg seems possible (Maak et al., 1999, 2001a ; 2001b). Among the fragments strongly displayed in the splay leg muscle, are identified the porcine $C D K N 3$ gene (cyclin-dependent kinase inhibitor 3) (Maak et al., 2002). CDKN3 belongs to a family of dual-specificity protein phosphatases and is involved in cell cycling (Gyuris et al., 1993; Hannon et al., 1994; Maak et al. 2003). Recently, Maak et al. (2009), comparing genome wide gene expression of three hind leg muscles (M. adductores, M. gracilis and M. sartorius) between splaylegged piglets and their healthy littermates, found that four genes with different expression levels in at least two muscles are assigned to transcriptional cascades related to cell death. However, histomorphological investigations, analysis of biochemical criteria as well as investigations on putative candidate genes lead to contradictory results (Ward and Bradley, 1980; Jirmanova, 1983; Ooi et al., 2006; Boettcher et al., 2007; 2008). Ooi et al. (2006) described congenital splay leg as muscle fiber atrophy characterized by an increased expression of the atrophy marker FBXO32 (atrogin, MAFbx) and histological signs of a generalized muscle fiber hypoplasia in skeletal muscles of splay leg piglets (Ooi et al., 2006). In addition, other researchers reported a large individual variability in FBXO32 expression as well as in histological characteristics of hind limb muscles, which has previously been described (Björklund et al., 1987; Curvers et al., 1989). A congenital, impaired functionality of skeletal hind limb muscles due to immaturity and/or atrophic properties is likely to be the major pathomorphological feature in splay leg syndrome.

Various management and genetic factors have been connected with the etiology of splay leg syndrome, such as the farrowing induction, low birth weight, short gestation lengths, slippery floors and breeds (e.g., Large White and Landrace pigs) (Ward, 1978). Moreover, nutrition can play a role to pathogenesis, as choline or methionine deficiency in sow diets are correlated with the presence of slay leg syndrome. Some researchers supported that one cause of splayleg was a deficiency in the sow's diet of choline and methionine which are essential for normal myelin production (Kornegay and Meacham, 1973). In contrast, the addition of $3 \mathrm{~g}$ choline and $5 \mathrm{~g}$ methionine to the sows' daily ration feed had no effect on the occurrence of splayleg (Dobson, 1971). Finally, nutrition also is involved in etiological factors and especially the fusarium toxicity. The contamination of feed in sows with more than 4 ppm zearalenone can result in increase in the number of piglets born with splay-leg from sows (Kanora and Maes, 2009).

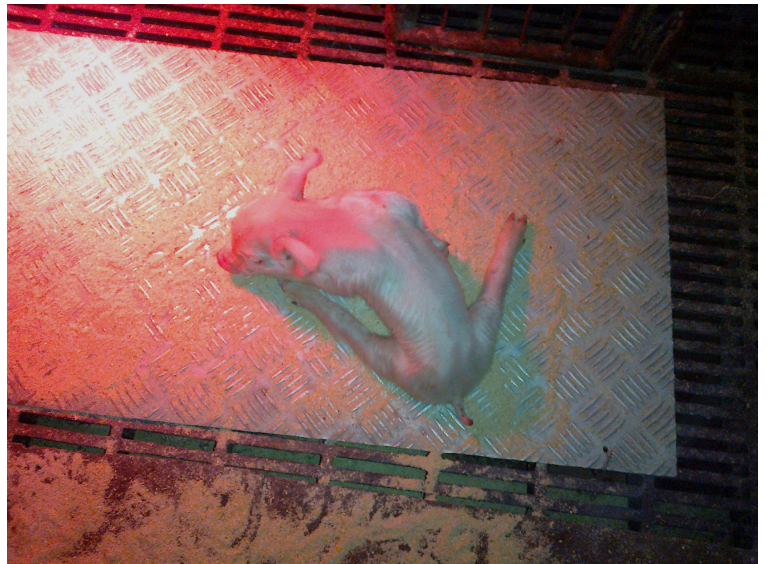

Fig. 1: A 6-days-old piglet at with splay leg syndrome

During the entire gestation, the same contamination leads to a reduced weight of the fetuses and a larger weight variation between piglets of the same litter (Etienne and Jemmali, 1982). It also leads to found a negative association between the plasma level of zearalenone and average birth weight of the piglets (Young and King, 1986).

Furthermore, infectious factors might be also involved in etiology. Porcine Reproductive and Respiratory Syndrome Virus (PRRSV) cause late term reproductive failure in sows, which is characterized by increased number of stillbirth, weak, light weight and splay-legged piglets (Papatsiros et al., 2006; Zimmerman et al., 2006).

Clinical signs: Affected piglets are characterized by an obvious weakness of the hind limbs immediately after birth leading to impaired mobility (Bergmann, 1976). Consequently, losses among splay leg piglets amount to 15-50\% (Hörügel and Lorenz, 1979; Wrathall, 1988; Svendsen et al., 1991).

Clinically, pigs show extreme abduction of the limbs with an inability to stand (Fig. 1). Splay leg affects the hindlimb adductors and in severe cases the forelegs are also involved (Szalay et al., 2001). Usually, $50 \%$ of affected piglets die due to starvation and overlying, because the pigs have difficulties in reaching the udder, retaining hold of the nipple, competing with their littermates and moving out of the sows lying space (Dewey et al., 2006). Affected pigs can be kept alive if they are fed artificially including colostrums, nursed well and have their limbs taped in a natural standing pose. By 6 days of age, the splay legged pigs do not differ from normal piglets clinically or in the histology of the muscles. Piglets that live past the first week of life will recover completely (Dewey et al., 2006). 
Treatment and control: First of all, piglets suffering from splay leg should be kept in warm conditions. They also should be helped to take colostrums or artificial milk for 2-3 days. The most common practice is the taping the hind limbs together or the use of elastic bands, improving piglets' ability to stand, suckle and move around until the legs strengthen. In addition, the repeated massage of the hind limbs seems to improve their survival.

Management practices should be applied in order to be avoided the occurrence of splay leg syndrome. For example, non-slip floors can improve footing and viability of piglets. Moreover, the use of antimycotoxins products in feed in order to prevent the zearalenone toxicity can be beneficial. In cases of feed contamination by zearalenone, the contaminated sow feed should be removed, but this takes up to 14 days to reduce the levels of zearalenone in milk and thus fostering or artificial feeding may be required to reduce mortality and aid recovery. The farrowing induction using prostaglandines should be also avoided before day 113 .

Finally, a herd health management programme should be applied in order to prevent and control PRRSV infection. The main target of such programme is mainly to minimize the virus transmission and circulation in breeding stock, as well as to maximize the herd immunity against PRRSV. Key points of this programme should be the establishment of strict biosecurity measures, acclimatization of replacement gilts by exposure to the specific PRRSV circulating on farm, as well as the application of appropriate vaccination programme (Papatsiros, 2011; 2012).

\section{CONCLUSION}

Management practices should be applied in order to be avoided the occurrence of splay leg syndrome, such as non-slip floors, use of anti-mycotoxins products in feed, avoiding the farrowing induction before day 113 . Finally, a herd health management programme should be applied in order to prevent and control PRRSV infection.

\section{REFERENCE}

Bergmann, V., 1976. Elektronenmikroskopische befunde an der skelettmuskulatur von neugeborenen ferkeln mit grätschstellung. Arch. Experim. Vet., 30: 239-260.

Björklund, N.E., J. Svendsen and L.S. Svendsen, 1987. Histomorphological studies of the perinatal pig: Comparison of five mortality groups with unaffected pigs. Acta Vet. Scand., 28: 105-116. PMID: 3687641
Boettcher, D., S. Paul, J. Bennewitz, H.H. Swalve and G. Thaller et al., 2007. Exclusion of NFYB as candidate gene for congenital splay leg in piglets and radiation hybrid mapping of further five homologous porcine genes from human chromosome 12 (HSA12). Cytogen. Gen. Res., 118: 67-71. DOI: $10.1159 / 000106443$

Boettcher, D., R. Schmidt, C. Rehfeldt, G. Thaller and H.H. Swalve et al., 2008. Evaluation of MAFbx expression as a marker for congenital splay leg in piglets. Dev. Biol. (Basel), 132: 301-306. PMID: 18817317

Curvers, P., R. Ducatelle, P. Vandekerckhoveet, W. de Coster and A. Calus et al., 1989. Morphometric evaluation of myofibrillar hypoplasia in splayleg piglets. Dtsch. Tierarztl. Wochenschr., 96: 189191. PMID: 2653778

Dewey, C.E., 2006. Diseases of the Nervous and Locomotor Systems. In: Diseases of Swine. Straw, B.E., J.J. Zimmerman, S.D. Allaire and D.J. Taylor (Eds.). Blackwell Publishing Professional, Ames, Iowa, USA., ISBN-13: 9780813817033, pp: 87-111.

Dobson, K.J., 1971. Failure of choline and methionine to prevent splayleg in piglets. Austral. Vet. J., 47: 587-590. PMID: 5137938

Dobson, K.J., 1968. Congenital splayleg of piglets. Austral. Vet. J., 44: 26-28. DOI: 10.1111/j.17510813.1968.tb04909.x

Etienne, M. and M. Jemmali, 1982. Effects of zearalenone (F2) on estrous activity and reproduction in gilts. J. Anim. Sci., 55: 1-10. PMID: 6214538

Hannon, G.J., D. Casso and D. Beach, 1994. KAP: A dual specificity phosphatase that interacts with cyclin-dependent kinases. Proc. Natl. Acad. Sci. USA, 91: 1731-1735.

Hillert, S., E. Kolb and A. Buchner, 1987. Untersuchungenüberden gehaltan DNA, RNA, protein und nicht-protein- $n$ in geweben von normal entwickelten ferkeln sowie von grätschferkeln sehr unterschiedlicher geburtsmasse (1. mitteilung). Arch. Experim. Vet. Med., 41: 65-77.

Hörügel, K. and A. Lorenz, 1979. Untersuchungen zum angeborenen beinspreizen bei Ferkeln in einer industriemäßig produzierenden zuchtanlage. Math. Vet. Med., 34: 183-184.

Jirmanova, I., 1983. The splayleg disease: A form of congenital glucocorticoid myopathy? Vet. Res. Commun., 6: 91-101. DOI: 10.1007/BF02214901

Kanora, A. and D. Maes, 2009. The role of mycotoxins in pig reproduction: A review. Vet. Med., 54: 565-576.

Lax, T., 1971. Hereditary splayleg in pigs. J. Hered., 62: 250-252. 
Maak, S., D., Boettcher, J. Tetens, M. WenschDorendorf and G. Nürnberg et al., 2009. Identification of candidate genes for congenital splay leg in piglets by alternative analysis of DNA microarray data. Int. J. Biol. Sci., 5: 331-337. DOI: 10.7150/ijbs.5.331

Maak, S., S. Jaesert, K. Neumann and G. von Lengerken, 2003. Characterization of the porcine CDKN3 gene as a potential candidate for congenital splay leg in piglets. Genet. Sel. Evol. 35: 157-165. DOI: $10.1051 /$ gse:2003024

Maak, S., S. Jaesert, K. Neumann, M. Yerle and G. von Lengerken, 2001a. Rapid communication: Chromosomal localization and partial cDNA sequence of the porcine ATP synthase, H+ transporting, mitochondrial F0 complex, subunit e (ATP5I) gene. J. Anim. Sci., 79: 1352-1353. PMID: 11374558

Maak, S., S. Jaesert, K. Neumann, M. Yerle and G. von Lengerken, 2001b. Isolation of expressed sequence tags of skeletal muscle of neonatal healthy and splay leg piglets and mapping by somatic cell hybrid analysis. Anim. Genet., 32: 303-307. PMID: 11683718

Maak, S., S. Jaesert and G. von Lengerken, 1999. Identification of candidate genes for congenital splay leg in piglets-first results. Arch. Anim. Breed., 42: 167-169.

Ooi, P.T., N. da Costa, J. Edgar, K.C. Chang, 2006. Porcine congenital splayleg is characterised by muscle fibre atrophy associated with relative rise in MAFbx and fall in P311 expression. BMC Vet. Res., 2: 23-23. PMID: 16869957

Papatsiros, V.G., C. Alexopoulos, S.K. Kritas, G. Koptopoulos and H.J. Nauwynck et al., 2006. Long-term administration of a commercial Porcine Reproductive And Respiratory Syndrome Virus (PRRSV)-inactivated vaccine in PRRSVendemically infected sows. J. Vet. Med. B Infect. Dis. Vet. Public Health, 53: 266-272. DOI: 10.1111/j.1439-0450.2006.00965.x

Papatsiros, V.G., 2012. Porcine Herd Health Management Practices for the Control of PRRS Infection. In: A Bird's-Eye View of Veterinary Medicine, Perez-Marin C.C., (Ed.). Greece, ISBN13: 97895351-00317, pp: 281-300.

Papatsiros, V.G., 2011. PRRSV and PCV-2 infections in greek swine farms: Clinical forms and vaccination programmes. Vet. Scan.

Partlow, G.D., K.R. Fisher, P.D. Page, K. MacMillan and A.F. Walker, 1993. Prevalence and types of birth defects in Ontario swine determined by mail survey. Can. J. Vet. Res., 57: 67-73.
Prange, H., S. Maak and U. Geipel, 2001. Investigations on congenital splayleg syndrome in newborn piglets. Proceedings of the 34th Annual Meeting of the GVMS "Physiology and Pathology of Reproduction, Feb. 22-23, pp: 34-34.

Sellier, P. and O. Ollivier 1982. Étudegénétiquedusyndromedel'abductiondesmemb res (splay leg) chez le porcelet nouveau-né. Modèle multifactoriel à un seuil, Ann. Génét. Sél. Anim., 14: 77-92.

Svendsen, L.S., B.R. Westrom, J. Svendsen, A.C. Olsson and B.W. Karlsson, 1991. Blood serum characteristics of newborn pigs: Comparison of unaffected pigs with pigs belonging to five mortality groups. Acta Vet. Scand., 32: 287-299. PMID: 1814177

Szalay, F., A. Zsarnovszky, S. Fekete, I. Hullar and V. Jancsik, et al., 2001. Retarded myelination in the lumbar spinal cord of piglets born with spread-leg syndrome. Anat. Embryol., 203: 53-59. DOI: 10.1007/s004290000129

Thurley, D.C., F.R. Gilbert and J.T. Done, 1967. Congenital splayleg of piglets: myofibrillar hypoplasia. Vet. Rec., 80: 302-304. PMID: 6067658

Ward, P.S. and R. Bradley, 1980. The light microscopical morphology of the skeletal muscles of normal pigs and pigs with splayleg from birth to one week of age. J. Comput. Pathol., 90: 421-431. DOI: 10.1016/0021-9975(80)90012-2

Wrathall, A.E., 1988. The boar and congenital problems. Pig Vet. Soc. Proc., 21: 116-134.

Young, L.G. and G.J. King, 1986. Low concentrations of zearalenone in diets of mature gilts. J. Anim. Sci., 63: 1191-1196. PMID: 2945808

Zimmerman, J.J., D.A. Benfield, M.P. Murtaugh, F.A. Osorio and G.W. Stevenson et al., 2006. Porcine Reproductive and Respiratory Syndrome Virus (Porcine Arterivirus). In: Diseases of Swine. Straw, B.E., J.J. Zimmerman, S.D. Allaire and D.J. Taylor (Eds.). Blackwell Publishing Professional, Ames, Iowa, USA, ISBN-13: 9780813817033, pp: 387-417.

Ward, P., 1978. The Oxford companion to Spanish literature. 1st Edn., Clarendon Press, Oxford, pp: 629.

Gyuris, J., E. Golemis, H. Chertkov and R. Brent, 1993. Cdi1, a human $\mathrm{G} 1$ and $\mathrm{S}$ phase protein phosphatase that associates with Cdk2. Cell, 75: 791-803. PMID: 8242750

Maak, S., S. Jaesert, K. Neumann and G.V. Lengerken, 2002. Rapid communication: nucleotide sequence and physical mapping of the porcine CyclinDependent Kinase Inhibitor 3 (CDKN3) gene. J Anim. Sci., 80: 1698-1699. 